No 4077

Studia nad Autorytaryzmem i Totalitaryzmem 43, nr 3

Wrocław 2021

https://doi.org/10.19195/2300-7249.43.3.23

\author{
NORBERT CZECHOWSKI \\ ORCID: 0000-0003-1639-3200 \\ Uniwersytet Wrocławski \\ 272501@uwr.edu.pl
}

\title{
Przedsiębiorcy odpowiedzialni społecznie wobec reżimów totalitarnych i autorytarnych
}

Słowa kluczowe: społeczna odpowiedzialność biznesu, przedsiębiorcy, prawa człowieka, totalitaryzm, autorytaryzm.

\section{SOCIALLY RESPONSIBLE ENTREPRENEURS TOWARDS TOTALITARIAN AND AUTHORITARIAN REGIMES}

\begin{abstract}
Increasingly, there are voices of dissatisfaction in the public opinion towards the actions of entrepreneurs who indirectly support authoritarian or totalitarian authorities. The aim of this article is to find an answer to the question whether a socially responsible entrepreneur, obliged to respect and protect human freedoms and rights, can undertake actions supporting totalitarian and authoritarian regimes. When looking for answers, I will refer to business ethics, the concept of corporate social responsibility, soft law, as well as to normative obligations under national law.
\end{abstract}

Keywords: corporate social responsibility, entrepreneurs, human rights, totalitarianism, authoritarianism.

\section{Wstęp}

Kiedy stosunki między państwami Unii Europejskiej a Białorusią stają się coraz bardziej napięte, aktualne staje się pytanie: jaki stosunek powinni mieć przedsiębiorcy do reżimów totalitarnych i autorytarnych? ${ }^{1}$ Przykład Nestlé S.A.

1 https://bialystok.wyborcza.pl/bialystok/7,35241,27586555,bialystok-protestowali-przeciw -wspieraniu-przez-koncern-ikea.html (dostęp: 21.09.2021); https://www.forest-monitor.com/pl/ikeana-bialorusi-a-polityka/ (dostęp: 21.09.2021). 
pokazuje, że nie są to rozważania abstrakcyjne ${ }^{2}$. Dzisiaj odpowiedź na pytanie, czy przedsiębiorcy mogą pozostać obojętni na łamanie praw i wolności człowieka, wydaje się szczególnie istotna, ponieważ nigdy wcześniej w historii nie mieli oni tak ogromnej siły. Kiedy Thomas Hobbes pisał o Lewiatanie ${ }^{3}$, być może nie przypuszczał, że siła, jaką widzi w państwie, stanie się niebawem udziałem przedsiębiorców. Dla niektórych zaskakujący może być fakt, że spośród 100 największych gospodarek świata tylko 31 to państwa narodowe, 69 zaś to korporacje $^{4}$. Problem pojawia się wtedy, gdy ogromne zasoby są wykorzystywane na cele, które wydają się sprzeczne nie tylko z ogólnoludzkim poczuciem słuszności, lecz także ze spoczywającymi na przedsiębiorcach zobowiązaniami. W przedmiotowym artykule omówię spoczywający na przedsiębiorcach obowiązek poszanowania i ochrony wolności i praw człowieka oraz poszukam odpowiedzi, czy może on pozostać w zgodzie $\mathrm{z}$ finansowym wspieraniem reżimów autorytarnych i totalitarnych. W swoich rozważaniach odwołam się do etyki prowadzenia biznesu, koncepcji społecznej odpowiedzialności biznesu, soft law, a także do normatywnych regulacji prawa krajowego.

\section{Etyka biznesu i społeczna odpowiedzialność biznesu}

Rozpoczynając poszukiwanie odpowiedzi na zadane pytanie, należy odwołać się do etyki, a nawet do religii, z którą powszechnie wiąże się początek etyki biznesu. Zagadnienia takie jak moralna ocena kapitalistycznych form gospodarowania pojawiały się $\mathrm{w}$ encyklikach papieskich, dając początek społecznemu nauczaniu Kościoła ${ }^{5}$. Refleksje te szybko trafily na uniwersytety w Stanach Zjednoczonych i następnie na społecznie podatny grunt lat sześćdziesiątych, kiedy to ogólny niepokój, spowodowany w znacznej mierze wojną z Wietnamem, doprowadził do zainteresowania opinii publicznej tematami takimi jak wytwarzanie odpadów nuklearnych czy korupcja ${ }^{6}$. Jedną z reakcji na to nowe zjawisko było podjęcie przez wydziały ekonomiczne uniwersytetów amerykańskich kwestii społecznej roli i odpowiedzialności przedsiębiorców, co doprowadziło do

2 https://forsal.pl/biznes/aktualnosci/artykuly/8198389, nestle-wycofa-reklamy-z-bialorus kiej-telewizji-apel-52-organizacji.html (dostęp: 21.09.2021).

3 T. Hobbes, Lewiatan czyli Materia, forma i władza państwa kościelnego i świeckiego, przeł. C. Znamierowski, Warszawa 1954.

${ }^{4}$ https://www.globaljustice.org.uk/news/69-richest-100-entities-planet-are-corporations-notgovernments-figures-show (dostęp: 21.03.2021).

${ }^{5}$ Leon XIII, Rerum novarum, http://www.vatican.va/content/leo-xiii/en/encyclicals/docume nts/hf_l-xiii_enc_15051891_rerum-novarum.html (dostęp: 3.04.2021); Pius XI, Quadragesimo Anno, http://nonpossumus.eu/encykliki/Pius_XI/quadragesimo_anno/II.php (dostęp: 3.04.2021).

${ }^{6}$ M. Rybak, Spoteczna odpowiedzialność biznesu - idea i rzeczywistość, „Gospodarka Narodowa. The Polish Journal of Economic" 2001, nr 3, s. 25. 
powstania etyki biznesu w jej obecnym rozumieniu ${ }^{7}$. Można jej przypisać postać etyki zawodowej, tworzącej wzór reguł pomocnych menedżerom w sytuacjach niejednoznacznych ${ }^{8}$. Innym jej przykładem mogą być maksymy konkretnych przedsiębiorców i wyrażane przez nich zobowiązanie, na przykład dbania o ogólny dobrobyt ludzkości ${ }^{9}$. Można więc wyobrazić sobie sytuację, kiedy konkretny menedżer, kierując się regułami wynikającymi z etyki, zrezygnuje z zawarcia kontraktu $\mathrm{z}$ władzami państwa totalitarnego lub autorytarnego, aby finansowo nie wspierać reżimu naruszającego wolności i prawa jednostki. Jakkolwiek takie działania zapewne mają miejsce, to jednak wpływ etyki biznesu na świat wciąż spotyka nieprzekraczalną barierę. Mianowicie fakt, że etyka może być zdefiniowania w kontekście jednostkowym - to ludzie mają etykę, organizacje jej nie mają, a co więcej - etyka nie jest absolutna, jest względna ${ }^{10}$. Uważam zatem, że chociaż jej rola w przypisywaniu przedsiębiorcom obowiązku dbania o wolności i prawa człowieka, w tym unikania prowadzenia interesów z władzami je naruszającymi, jest znacząca, to jednak sama etyka nie jest narzędziem w tej kwestii skutecznym i sama nie jest w stanie udzielić odpowiedzi na postawione na wstępie pytanie.

Bariery spotykane przez etykę biznesu być może doprowadziły do powstania kolejnej koncepcji społecznej odpowiedzialności biznesu (SOB), która także bywa różnie rozumiana ${ }^{11}$. Nie przeszkadza jej to jednak w przenikaniu do regulującej gospodarkę warstwy normatywnej. Niektórzy w SOB widzą szansę na połączenie biznesu i praw człowieka ${ }^{12}$. Słuszna moim zdaniem może wydawać się teza, że „SOB jest w jakimś sensie logiczną konsekwencją przyjętej kiedyś idei umowy społecznej i jej praktycznych realizacji we współczesnych społeczeństwach demokratycznych" "13. Wraz z rozwojem istnienia społeczeństwa obywatelskiego następuje coraz wyraźniejsze formułowanie adresowanych do przedsiębiorców postulatów. W konwekwencji przedsiębiorcy, odczuwając presję społeczną z jednej strony, a z drugiej spowodowane tą właśnie presją zmiany legislacyjne, coraz chętniej respektują założenia koncepcji SOB. Nie można zatem pozostawiać związku między demokracją a SOB niezauważonym, co widać na przykładzie

${ }^{7}$ C. Porębski, Czy etyka się opłata? Zagadnienia etyki biznesu, Kraków 1988, s. 15.

8 Ibidem, s. 140.

9 Ibidem, s. 143.

10 R.W. Griffin, Podstawy zarzadzania organizacjami, przeł. M. Rusiński, Warszawa 1997, s. 135.

11 K. Kazojć, Koncepcja społecznej odpowiedzialności i jej obszary w organizacjach, „Studia i Prace Wydziału Nauk Ekonomicznych i Zarządzania” 2014, nr 38(1), s. 58.

12 Zob. A. Bodnar, A. Ploszka, CSR a prawa człowieka - monitorowanie przestrzegania standardów społecznej odpowiedzialności biznesu przez spótki, „Przegląd Prawa Handlowego” 2014, nr 4, s. 31-39.

13 J. Filek, Społeczna odpowiedzialność biznesu jako nowa wersja umowy społecznej, Kraków 2013, s. 17. 
protestów wobec działań Nestlé S.A. ${ }^{14}$ Można więc w przedmiotowej koncepcji zauważyć spoczywający na przedsiębiorcach obowiązek respektowania wolności i praw człowieka, jednak zabezpieczeniem tego obowiązku może być jedynie presja społeczna, a to często okazuje się zabezpieczeniem niewystarczającym ${ }^{15}$.

\section{Soft law}

Społeczna odpowiedzialność biznesu stała się przedmiotem zainteresowań Komisji Europejskiej, co doprowadziło do powstania jej definicji, której można przypisać charakter soft law. Początkowo Komisja Europejska SOB uważała za koncepcję, zgodnie z którą przedsiębiorcy dobrowolnie uwzględniają problematykę społeczną i ekologiczną w swojej działalności komercyjnej i stosunkach $\mathrm{z}$ zainteresowanymi stronami, podkreślając jednocześnie jej dobrowolność ${ }^{16}$. Takie stanowisko zmieniło się jednak już w 2011 roku, kiedy Komisja, definiując $\mathrm{SOB}$, zrezygnowała $\mathrm{z}$ jej dobrowolnego charakteru, podkreślając jednocześnie, że jednym $z$ jej aspektów jest ochrona wolności i praw człowieka ${ }^{17}$. Dla ekspansji SOB na płaszczyznę normatywną było to wydarzenie przełomowe. W nowej strategii Komisja już na wstępie wyjaśniła, że SOB dotyczy podejmowanych przez przedsiębiorców działań nie tylko przekraczających wymagania ustawowe, lecz także wynikających bezpośrednio z przepisów prawa, co wydaje się tym bardziej uzasadnione, że w wielu krajach UE, w tym Polsce, przedmiotowe wartości przybrały szatę normatywną.

Innym przykładem soft law w przedmiotowej materii mogą być Wytyczne dla przedsiębiorstw wielonarodowych Organizacji Współpracy Gospodarczej i Rozwoju ${ }^{18}$, które w 2011 roku rozszerzono o rozdział poświęcony prawom człowieka, a które stanowią zestaw dobrowolnie akceptowanych przez przedsiębiorców zasad i praktyk. Zgodnie z pkt II Wytycznych ,przedsiębiorstwa powinny w pełni brać pod uwagę politykę prowadzoną w krajach, w których prowadzą działalność”, w tym ,przestrzegać praw człowieka osób, na które ich działalność ma wpływ". Przykładem ilustrującym działanie Wytycznych w praktyce może być

14 https://bialystok.wyborcza.pl/bialystok/7,35241,27586555,bialystok-protestowali-prze ciw-wspieraniu-przez-koncern-ikea.html (dostęp: 21.09.2021); https://www.forest-monitor.com/pl/ ikea-na-bialorusi-a-polityka/ (dostęp: 21.09.2021).

15 M. Szuleka, Bojkot konsumencki jako skuteczne narzędzie ochrony praw czlowieka, [w:] Biznes a prawa człowieka. Współczesny stan dyskusji, red. A. Ploszka, Warszawa 2017, s. 61-70.

16 Opinion of the Economic and Social Committee on the "Green Paper: Promoting a European framework for Corporate Social Responsibility" (COM(2001) 366 final), euro-lex nr 52002AE0355.

17 Komunikat Komisji do Parlamentu Europejskiego, Rady i Europejskiego Komitetu Ekonomiczno-Społecznego i Komitetu Regionów — odnowiona strategia UE na lata 2011-2014 dotycząca społecznej odpowiedzialności przedsiębiorstw, euro-lex nr 52011DC0681.

18 https://www.oecd.org/corporate/mne/38111315.pdf (dostęp: 23.09.2021). 
sprawa ForUM vs Aker Kvorner $A S A^{19}$. Aker Kværner ASA, za pośrednictwem swojej spółki córki KværnerProcess Services Inc., świadcząc usługi na rzecz Departamentu Obrony USA w zatoce Guantanamo, naruszyła, postanowienia Wytycznych dotyczące praw człowieka w zatoce Guantanamo na Kubie, między innymi przez utrzymywanie w więzieniach warunków, które naruszały godność człowieka i zasadę humanitaryzmu. Sprawą zajmował się Norweski Punkt Kontaktowy, który wydając rekomendację, stwierdził, że chociaż przedsiębiorcy nie są stronami aktów prawa międzynarodowego, do których naruszeń doszło w wypadku Guantanamo, to powinni oni jednak przestrzegać wolności i praw człowieka, w szczególności nie czerpać zysków z ich naruszania. Skutkiem zajęcia się sprawą przez Norweski Punkt Kontaktowy, niebędący organem uprawnionym do autorytatywnego orzekania o prawach i obowiązkach przedsiębiorcy, było wycofanie się Aker Kværner ASA z Guantanamo, więc sprawa zakończyła się sukcesem.

$\mathrm{Na}$ koniec warto wspomnieć o stadium pośrednim między soft law a bezwzględnie obowiązującymi normami prawnymi, z których wynika obowiązek poszanowania wolności i praw człowieka przez przedsiębiorców, to jest Wytycznych ONZ dotyczących biznesu i praw człowieka ${ }^{20}$. Określane mianem końca początku kwestii zobowiązania przedsiębiorców do przestrzegania praw człowieka szybko stały się elementem porządków normatywnych wielu państw, w tym Polski ${ }^{21}$. W praktyczną realizację przedmiotowych Wytycznych bardzo zaangażowała się UE, zobowiązując państwa członkowskie do skutecznego ich wdrożenia.

\section{Obowiązki normatywne}

Wykonując opisany w poprzednim podrozdziale obowiązek, Polska przygotowała Krajowy Plan Działania na rzecz wdrażania Wytycznych ONZ dotyczących biznesu i praw człowieka 2017-2020. Jednym z jego elementów było dodanie do powstającej wówczas konstytucji biznesu 22 przepisu, z którego wynikałby obowiązek poszanowania i ochrony przez przedsiębiorców wolności i praw człowieka ${ }^{23}$.

Artykuł 9 ustawy z dnia 6 marca 2018 roku — Prawo przedsiębiorców ${ }^{24}$ o treści: , przedsiębiorca wykonuje działalność gospodarczą zgodnie z zasadami uczciwej konkurencji, poszanowania dobrych obyczajów oraz słusznych interesów in-

19 https://www.oecdwatch.org/complaint/forum-vs-aker-kvaerner-asa/ (dostęp: 23.09.2021).

$20 \mathrm{https} / /$ www.gov.pl/web/dyplomacja/krajowy-plan-dzialania-na-rzecz-wdrazania-wytycz nych-onz-dotyczacych-biznesu-i-praw-czlowieka-2017-2020 (dostęp: 27.09.2021).

21 C. Rodriguez-Garavito, Business and Human Rights Beyond the End of the Beginning, Cambridge 2017.

22 https://www.gov.pl/attachment/a420f8dd-c343-49e0-bbb4-2e10772a8447 (dostęp: 27.09. 2021).

23 https://www.gov.pl/attachment/84704af6-1470-428c-82d4-d6bfeddd9c2a (dostęp: 27.09. 2021).

24 Tekst jedn. z dnia 8 grudnia 2020 r., Dz.U. z 2021 r. poz. 162. 
nych przedsiębiorców i konsumentów, a także poszanowania oraz ochrony praw i wolności człowieka" wszedł w życie 30 kwietnia tegoż roku. Mający swój początek w etyce biznesu obowiązek został umiejscowiony wśród zasad naczelnych najważniejszej dla publicznego prawa gospodarczego ustawie, stanowi zatem element klamry spinającej podstawowe reguły prowadzenia działalności gospodarczej ${ }^{25}$. Niestety nie stał się on jednak latarnią wskazującą przedsiębiorcom, w jaki sposób powinni oni działać na rzecz realizacji idei wolności i praw człowieka. Być może dlatego, że użyte przez ustawodawcę pojęcia o uniwersalnym znaczeniu zmuszają do poszukiwania treści omawianego obowiązku poza płaszczyzną wyłącznie normatywną, niezbędne są również odwołania do pojęć pozaprawnych, a nawet wykraczających poza sferę stosunków gospodarczych ${ }^{26}$. Nie bez znaczenia zatem dla zrozumienia omawianej regulacji jest odwołanie się do etyki biznesu, społecznej odpowiedzialności biznesu, soft law, z którego przedmiotowe uregulowanie bierze swój początek, a także do odczuć społeczeństwa obywatelskiego, które na działalność przedsiębiorców potrafi mieć znaczący wpływ ${ }^{27}$.

\section{Podsumowanie}

Trudno dziś jednoznacznie rozstrzygnąć, czy przedsiębiorca, zobowiązany do poszanowania i ochrony wolności i praw człowieka, może podejmować działania wspierające reżimy totalitarne i autorytarne, ponieważ przepisy regulujące tę kwestię nie są wystarczająco ostre, a co więcej brakuje konkretnego środka prawnego pozwalającego przedmiotowy obowiązek wyegzekwować. Nie ulega jednak wątpliwości, że odpowiedź na przedmiotowe pytanie będzie stanowcza w stosunku do przedsiębiorcy odpowiedzialnego społecznie, czyli takiego, który w swojej strategii prowadzenia działalności gospodarczej zobowiązał się do respektowania koncepcji społecznej odpowiedzialności biznesu, czy to przez przyjęcie konkretnej maksymy, stworzenie kodeksu postępowania dla menedżerów, czy zaakceptowanie Wytycznych Organizacji Współpracy Gospodarczej i Rozwoju. Od nas natomiast jako społeczeństwa będzie zależało, czy przedsiębiorcy rzeczywiście będą chcieli stać się odpowiedzialni. Jeśli tak, to ich wsparcie, nawet pośrednie, wobec reżimów totalitarnych i autorytarnych nie powinno mieć miejsca.

25 A. Kraszewski, Podstawowe zasady wykonywania działalności gospodarczej, [w:] Prawo przedsiębiorców. Komentarz, red. A. Pietrzak, Warszawa 2019, art. 9.

${ }^{26}$ K. Kokocińska, Obowiązek wykonywania działalności gospodarczej zgodnie z zasadami uczciwej konkurencji i poszanowania dobrych obyczajów, [w:] Konstytucja biznesu. Komentarz, red. M. Wierzbowski, Warszawa 2019, art. 9.

27 M. Szuleka, Bojkot konsumencki jako skuteczne narzędzie ochrony praw czlowieka, [w:] Biznes a prawa człowieka. Wspótczesny stan dyskusji, red. A. Ploszka, Warszawa 2017, s. 61-70. 


\section{Bibliografia}

Bodnar A., Ploszka A., CSR a prawa czlowieka - monitorowanie przestrzegania standardów spotecznej odpowiedzialności biznesu przez spółki, „Przegląd Prawa Handlowego” 2014, nr 4.

Carnegie A., Ewangelia bogactwa, przeł. H. Górnicka-Holeczek, Poznań 2012.

Filek J., Społeczna odpowiedzialność biznesu jako nowa wersja umowy społecznej, Kraków 2013.

Griffin R.W., Podstawy zarzadzania organizacjami, przeł. M. Rusiński, Warszawa 1997.

Hobbes T., Lewiatan czyli Materia, forma i władza państwa kościelnego i świeckiego, przeł. C. Znamierowski, Warszawa 1954.

Kazojć K., Koncepcja społecznej odpowiedzialności i jej obszary w organizacjach, „Studia i Prace Wydziału Nauk Ekonomicznych i Zarządzania" 2014, nr 38(1).

Kokocińska K., Obowiąek wykonywania działalności gospodarczej zgodnie z zasadami uczciwej konkurencji i poszanowania dobrych obyczajów, [w:] Konstytucja biznesu. Komentarz, red. M. Wierzbowski, Warszawa 2019.

Kołodko G.W., Nowy pragmatyzm i jego znaczenie dla uczciwego gospodarowania, [w:] Etyka i ekonomia. W stronę nowego paradygmatu, red. E. Mączyńska, J. Sójka, Warszawa 2017.

Kraszewski A., Podstawowe zasady wykonywania działalności gospodarczej, [w:] Prawo przedsiębiorców. Komentarz, red. A. Pietrzak, Warszawa 2019, art. 9.

Leon XIII, Rerum novarum, http://www.vatican.va/content/leo-xiii/en/encyclicals/documents/hf_lxiii_enc_15051891_rerum-novarum.html.

Pius XI, Quadragesimo Anno,http://nonpossumus.eu/encykliki/Pius_XI/quadragesimo_anno/II.php.

Porębski C., Czy etyka się opłaca? Zagadnienia etyki biznesu, Kraków 1988.

Rodriguez-Garavito C., Business and Human Rights Beyond the End of the Beginning, Cambridge 2017.

Rybak M., Społeczna odpowiedzialność biznesu - idea i rzeczywistość, „Gospodarka Narodowa. The Polish Journal of Economics" 2001, nr 3.

Szuleka M., Bojkot konsumencki jako skuteczne narzędzie ochrony praw człowieka, [w:] Biznes a prawa człowieka. Współczesny stan dyskusji, red. A. Ploszka, Warszawa 2017.

\section{Akty prawne}

Ustawa z dnia 6 marca 2018 r. — Prawo przedsiębiorców, tekst jedn. z dnia 8 grudnia 2020 r., Dz.U. z 2021 r. poz. 162.

\section{Źródła internetowe}

https://bialystok.wyborcza.pl/bialystok/7,35241,27586555,bialystok-protestowali-przeciw-wspie raniu-przez-koncern-ikea.html.

https://forsal.pl/biznes/aktualnosci/artykuly/8198389, nestle-wycofa-reklamy-z-bialoruskiejtelewizji-apel-52-organizacji.html.

https://www.forest-monitor.com/pl/ikea-na-bialorusi-a-polityka/.

https:/www.gazetaprawna.pl/wiadomosci/swiat/artykuly/8093578,twitter-usunal-konto-trumpa-wy bory-prezydenckie.html.

https://www.globaljustice.org.uk/news/69-richest-1.00-entities-planet-are-corporations-not-go vernments-figures-show.

https://www.gov.pl/attachment/a420f8dd-c343-49e0-bbb4-2e10772a8447. 
https://www.gov.pl/web/dyplomacja/krajowy-plan-dzialania-na-rzecz-wdrazania-wytycznych-onzdotyczacych-biznesu-i-praw-czlowieka-2017-2020.

https://www.oecd.org/corporate/mne/38111315.pdf.

https://www.oecdwatch.org/complaint/forum-vs-aker-kvaerner-asa/.

Komunikat Komisji dla Parlamentu Europejskiego, Rady i Europejskiego Komitetu Ekonomiczno-Społecznego i Komitetu Regionów - Odnowiona strategia UE na lata 2011-2014 dotycząca społecznej odpowiedzialności przedsiębiorstw, euro-lex nr 52011DC0681.

Opinion of the Economic and Social Committee on the "Green Paper: Promoting a European framework for Corporate Social Responsibility" (COM(2001) 366 final), euro-lex nr 52002AE0355. 